provision and police practice might also influence the frequency of use.

Section 136 is a cheap and potentially effective way of diverting mentally disordered persons from police custody. This can prevent them proceeding to the more costly and distressing processes of the criminal justice system. However, evidence suggests that the police see section 136 procedures as cumbersome, time-consuming and frustrating and tend to under-identify mental disorder rather than over-identify it (Dunn \& Fahy, 1990). These findings, together with our own results obtained from the health service, suggest that the current use of section 136 is unsatisfactory. In particular, we would suggest that the demonstrated absence of agreed guidelines is likely to discourage the police further from pursuing section 136 in appropriate cases and the option of early diversion from the criminal justice system to the health service is likely to be missed.

We would recommend that all district health authorities without a written policy should draw up a policy, following the Code of Practice of the Mental Health Act, in liaison with the police and social services. A psychiatrist with a special interest in the MHA among the clinical staff could facilitate this. Secondly, efforts should be made to disseminate the policy to all relevant personnel, not simply higher management. Thirdly, district health authority administrators should keep reliable records on all section 136 individuals, regardless of outcome. These records should include demographic data, time of section 136 application and time of assessment, and the profession of the assessors. Policies and records should be reviewed regularly by all parties involved and detected discrepancies between policy and practice should be addressed.

\section{References}

Department of Health AND Welsh Office (1990) Code of Practice Mental Health Act 1983. London: HMSO.

- /HOME OFFice (1992) Report of the research advisory group. Review of health and social services for mentally disordered offenders and others requiring similar services. Unpublished.

DUNN, J. \& FAHY, T. (1990) Police admissions to a psychiatric hospital. Demographic and clinical differences between ethnic groups. British Journal of Psychiatry. 166, 373-378.

Mental Health ACt Commission (1991) Fourth Blennial Report 1989-1991. London: HMSO.

RoBERTSON. G. (1992) Police disposal of mentally ill people in central London. Unpublished. Report to the Home Office.

ROGERS, A. \& FAULKNER, A. (1987) A Place of Safety. London: MIND.

Marinus P. Klijnsma, Senior Registrar, Warlingham Park Hospital, Warlingham, Surrey CR6 9YR; Annie E.A. Bartlett, Clinical Research Fellow; and Andrea Cohen, Audit Co-ordinator; Section of Forensic Psychiatry. St George's Hospital Medical School, London SW17 ORE

\title{
Defeat Depression Action Week
}

\section{3-11 March 1994 \\ Atms}

* to raise awareness about depression

* to reduce the stigma associated with it

* to give advice on seeking help

There will be a two mile fun run in Hyde Park, London, as part of the Defeat Depression
Action Week. This will start at 11 a.m. on Sunday, 6 March. The entry fee is $£ 3$ and the total amount received in entry fees will be matched by a commercial company and all proceeds will be donated to the Defeat Depression Campaign.

If you are interested in this event please contact Christine Gear on 0712352351. 